\title{
Mida räägib meile TALIS 2018 uuring õpetaja ja koolijuhi karjääriteest?
}

\author{
Merle Taimalu ${ }^{\mathrm{a}}$ \\ ${ }^{a}$ Tartu Ülikool, haridusteaduste instituut
}

Taimalu, M., Uibu, K., Luik, P., Leijen, Ä. (2019). Õpetajad ja koolijuhid elukestvate õppijatena. OECD rahvusvahelise õpetamise ja õppimise uuringu TALIS 2018 tulemused. 1. osa. Tallinn: Haridus- ja Teadusministeerium ja SA Innove.

Viimased PISA uuringud on andnud põhjust rõõmustada ja uhkust tunda Eesti haridussüsteemi ja õpetajate töö üle. Uued prioriteedid - kaasav haridus, mitmekesisem õpilaskond ja tehnoloogia areng - seavad meie koolidele väljakutseid ja uusi ootusi. Seetõttu on tähtis, et õpetajate ja koolijuhtide heaolu ja professionaalne areng oleks piisavalt toetatud kogu karjääritee vältel - et meie haridussüsteemi tugitalad oleksid oma tööga rahul ja tunneksid end väärtustatuna. Just professionaalsuse ja õpetajaameti atraktiivsuse teemale ongi keskendunud viimane TALISe uuring (The Teaching and Learning International Survey). Sügisel 2019 ilmus Eesti raporti esimene osa, mis keskendus eelkõige õpetajate ja koolijuhtide tööga seotud teadmistele ja oskustele. Järgnevalt tehaksegi raporti esimesse osasse väike sissevaade, mis loodetavasti tekitab lugejas huvi ja ajendab sellega lähemalt tutvuma.

OECD rahvusvahelises TALISe uuringus, mille fookuses on õpetamine ja õppimine, osalevad koolidirektorid ja kolmanda kooliastme õpetajad, kelle töö seostub kõige vahetumalt ka 15-aastaste õpilaste kõrgete PISA tulemustega. Esimeses TALISe uuringus 2008. aastal osales 24 riiki. 2018. aastal toimunud kolmandas uuringus osales juba 48 riiki. Eestist osales 3004 õpetajat 195 kooli kolmandast kooliastmest ja samade koolide 195 direktorit, kes andsid hinnanguid oma töö eri valdkondade kohta.

Nagu raporti esimese osa pealkirigi ütleb, ei saa õpetajad ja koolijuhid kunagi päris valmis, vaid nende professionaalne areng kestab kogu tööelu. Raportis on vaatluse all kogu karjääritee alates sellest, miks õpetaja on õpetajakutse valinud, lõpetades koolijuhi ja õpetaja professionaalse arengu tegevustes osalemisega. Keskendutakse eelkõige Eesti tulemustele, kuid tausta loomiseks 
on toodud kõrvale OECD riikide keskmisi tulemusi, aga ka naaberriikide Soome ja Läti ning huvitavamaid tulemusi mõne teise riigi näitel.

Raportist näeme, et õpetajate kasvava vanuse pärast muretsemise kõrval võime rõõmustada selle üle, et Eesti koolijuhid ja õpetajad on kõrgema haridustasemega kui OECD riikides keskmiselt ja kolmandas kooliastmes on uusi alustavaid, kuni viieaastase staažiga õpetajaid märksa rohkem kui viis aastat tagasi. TALIS 2018 uuringus oli esimest korda käsitletud õpetajakutse valikut mõjutanud tegureid, mis näitasid, et Eestis on rohkem kui teistes OECD riikides õpetajaid, kelle jaoks on ametivalikul olnud oluline, et õpetajal on kindel töökoht, töö sobib eraeluga ning pakub püsivat sissetulekut. Lisaks eristume teistest uuringus osalenud riikidest nais- ja meesõpetajate osakaalu kõige suurema erinevusega, kus meil on rohkem esimese karjäärieelistusena õpetajakutse valinud naisi kui mehi.

Kindlasti on meil põhjust rõõmustada, et õpetajate endi seas on oluliselt kasvanud õpetajaameti väärtustatuna tajumine, seda eriti kuni viieaastase staažiga õpetajate seas. Samas tuleb pöörata tähelepanu sellele, et kolmveerand kolmanda kooliastme õpetajatest veel ei tajunud õpetajaameti väärtustatust. Lisaks tuleb mõelda, kuidas õpetajaid ja koolijuhte karjääritee eri etappidel toetada ning milliseid töötingimusi ja toetussüsteeme luua, et nad tunneks end oma töös kindlana ning oleksid rahul ja õnnelikud. Kindlasti paneb olulise aluse tõhusaks tööks ja ametiga rahuloluks hea ettevalmistatus, millel järgnevalt peatutaksegi.

Pole üllatav, et õpetajatele küll õpetatakse nende ettevalmistuse jooksul eri valdkondi, kuid subjektiivne hinnang, kui hästi ettevalmistatuna nad end mingis valdkonnas tunnevad, on märksa kehvem. Võime öelda, et meie kolmanda kooliastme õpetajad tunnevad end hästi ettevalmistatuna eelkõige aine õpetamises, mis on ajast aega olnud õpetajate ettevalmistuse kese. Samas tuleks tõhusamalt tegelda valdkondadega, kus hästi ettevalmistatuna tundis end alla poole õpetajatest - näiteks õpilaste arengu ja õppimise jälgimises, klassi juhtimises ja üldoskuste õpetamises, aga ka õpetamisel IKT-vahendite kasutamises, erineva võimekusega õpilaste õpetamises ning mitmekultuurilises ja/või -keelses klassis õpetamises. Õpetajate ettevalmistuses ongi tehtud suuri muudatusi ja nende tulemused on ka näha TALIS 2018 uuringus. Vaadates kuni viieaastase staažiga algajate ópetajate hinnanguid oma ettevalmistatuse tasemele, näeme mõneski valdkonnas olulisi paranemistendentse, näiteks ettevalmistatuses kasutada õpetamisel IKTd.

Kui algaja või uus õpetaja kooli jõuab, siis on väga tähtis toetada tema sisseelamist - et kohanemine läheks võimalikult valutult ega tekitaks ülemäärast stressi. Nagu ütleb Madis Lepik Õpetajate Lehes (24.01.2020, lk 13), on õpetajate töös omad suured võlud, kuid need ei ilmne esimestel tööaastatel, 
vaid alles mõneaastase töökogemusega, seega tuleks õpetajat koolis hoida vähemalt niikaua, et ta jõuaks õpetajatöö positiivsete külgedeni. Enamikus koolides on õpetajatel sisseelamist soodustavatele tegevustele küll ligipääs, kuid need piirduvad üldise administratiivse sissejuhatuse, planeeritud kohtumistega koolijuhi ja/või kogenud õpetajaga ja nendepoolse juhendamisega. Vaid pool õpetajatest on saanud kohanemisajal teha koostööd teiste uute õpetajatega või õpetada koos kogenud õpetajaga. Samas oleksid just need väga väärtuslikud võimalused õpetaja sisseelamise toetamiseks. Samuti võiks madalam õpetamiskoormus vähemalt esimesel tööaastal koolis koos keskmise palga säilimisega kuuluda iga algaja õpetaja sisseelamisprogrammi, kuid uuringus nimetas sellist võimalust alla viiendiku õpetajatest.

Sisseelamist peaks toetama ka Eesti koolides juba aastaid olemasolev mentorlussüsteem, mistõttu on üllatav ja mõtlemapanev, et alla viiendikul kuni viieaastase õpetamiskogemusega õpetajatel oli olnud koolis mentor. Ka ise mentoriks olnuid oli alla kümnendiku ja mõnevõrra (kuigi mitte oluliselt) on see näitaja viie aastaga isegi vähenenud. Nii õpetaja sisseelamist toetavate tegevuste kui ka mentorluse teema vajaks kindlasti lähemat uurimist, et välja selgitada, kas ja kuidas tegelikult meie koolides alustavaid ópetajaid toetatakse ja milliseid tegevusi kohanemisel pakutakse. Kuna ka varasemad uuringud on näidanud üsna suurt õpetajate osakaalu, kes lahkuvad koolist töölt juba kahe kuni viie esimese aasta jooksul, on kohanemise toetamine ja eriti algajatele õpetajatele toe pakkumine väga oluline.

Muutunud olud ja nõudmised panevad õpetajale suure töökoormuse, mida iseloomustab ka õpetaja tööks kuluv aeg. Meie ópetajad töötavad üle seadusega ettenähtud koormuse - täis- ja osakoormuses õpetajate keskmine koondtulemus oli 35,7 tundi nädalas ja peame arvestama, et umbes kolmandik meie õpetajatest töötab osakoormusega. Seega on õpetaja tööaeg ja töötingimused endist viisi oluline valdkond, millest lähemalt räägitakse raporti teises osas. Positiivsena näeme, et Eesti kolmanda kooliastme õpetaja saab põhiosa õppetunni ajast pühendada sellele, milleks on tund ette nähtud - õpilaste õpetamisele. Tunnis õpetamise ja õppimisega tegelemine tundub iseenesestmõistetav, kuid näiteks OECD riikides keskmiselt peab õpetaja viiendiku õppetunnist tegelema muude tegevustega peale õpetamise. Lisaks suudab meie õpetaja võrreldes viie aasta taguse ajaga efektiivsemalt ja kiiremini tunde ette valmistada, hoides töönädalas kokku umbes tunni tööaega. Tõenäoline on, et seda võimaldab õpetaja suur töökogemus, tehnoloogiavõimaluste oskuslikum kasutus ja paljude õpetajate töötamine mitmes koolis, kus ilmselt õpetatakse ka samas vanuseastmes lastele sarnaseid teemasid.

Heaks õpetamiseks on väga tähtis, et õpetaja tunneb end töös hakkamasaajana. Üldiselt on Eestis kolmanda kooliastme õpetajate enesetõhusus 
suur nii õpilaste kaasamise, klassi juhtimise kui ka õpetamisega seotud valdkondades. Teistest madalam oli õpetajate enesetõhusus õppetöös IKT võimaluste kasutamisel. See on valdkond, kus õpetaja vajab endiselt koolitamist ja tuge, sest valdkond ise areneb väga kiiresti. Positiivsena võib märkida õpetajate enesetõhususe olulist tõusu 2013. aasta TALISe uuringuga võrreldes.

Püüdes end muutustega kursis hoida, on vaja järjepidevat enesetäiendust, mis kujundabki elukestva õppimise ja toetab professionaalset arengut. Hea on tõdeda, et Eesti õpetajad ja koolijuhid on enesetäiendamise suhtes kõrgelt motiveeritud ja positiivsete hoiakutega. Neid iseloomustab suur osalus professionaalse arengu tegevustes, näiteks õpetajad osalevad endi sõnul aastas keskmiselt viies ja koolijuhid keskmiselt seitsmes tegevuses. Mõne teema puhul tuntakse rohkem vajadust enesetäienduseks - näiteks seoses erivajadusega õppijate õpetamisega, kusjuures vajadus selliste enesetäienduse võimaluste järele on võrreldes TALIS 2013 uuringuga kasvanud. Samuti tuntakse rohkem vajadust enesetäienduse järele, mis puudutab mitmekultuurilises ja -keelses keskkonnas õpetamist ning õpetamisel IKT kasutamist. Ilmselt on nendes valdkondades enesetäienduse vajadus suurem seetõttu, et õpetajate esmases ettevalmistuses ei jõuta anda piisavalt põhjalikku ettevalmistust reaalses koolielus hakkamasaamiseks ja nendes valdkondades on toimunud suuremad ja kiiremad muutused seoses kaasava hariduse ja tehnoloogiavõimaluste arenguga.

Kuigi professionaalse arengu tegevusi pakutakse õpetajatele küllalt palju, võivad nendes osalust takistada tegurid, millest selgus kõige sagedasema takistusena pakutavate võimaluste sobimatus õpetaja töögraafikuga. Seetõttu tuleks koolides kavandada õpetajate professionaalset arengut süsteemselt ja planeerida koolitused aegsasti töögraafikusse. Professionaalse arengu tegevustes osalemine mõjutab ka õpetajate õpetamistegevust ja lisaks on enesetäienduses osalenud õpetajatel kõrgem enesetõhusus ja töörahulolu.

TALISe uuringu Eesti raporti esimest osa saab lugeda SA Innove kodulehel https://www.innove.ee/uuringud/talis-uuring/talis-2018/.

Eesti raporti teine osa ilmub 2020. aasta kevadel ja sealt leiab lugeja tulemused järgmistes valdkondades: kooli juhtimine ja õpetajate töö hindamine koolijuhtide vaates, tagasiside saamine oma tööle õpetajate vaatenurgast ning koolikliima ja tööga rahulolu nii õpetajate kui ka koolijuhtide vaates. Samuti käsitletakse õpetajate koostöö ja kooli koostöökultuuri, aga ka õpetajate ja koolijuhtide töökoormuse ja töötingimuste temaatikat. 